\title{
Herb species inclusion in grazing swards for dairy cows-A systematic review and meta-analysis
}

\author{
K. M. McCarthy, ${ }^{1,2 *} \odot$ C. G. McAloon, ${ }^{2}$ M. B. Lynch, ${ }^{3}$ K. M. Pierce, ${ }^{3} \odot$ and F. J. Mulligan ${ }^{2} \odot$ \\ ${ }^{1}$ UCD Lyons Research Farm, Lyons Estate, Celbridge, Naas, Co. Kildare W23 ENY2, Ireland \\ ${ }^{2}$ School of Veterinary Medicine, University College Dublin, Belfield, Dublin 4 D04 W656, Ireland \\ ${ }^{3}$ School of Agriculture and Food Science, University College Dublin, Belfield, Dublin 4, Ireland
}

\begin{abstract}
A systematic review and meta-analysis were conducted to estimate the effect of herb species on milk production and urinary nitrogen (UN) excretion from grazing dairy cows. Grazing swards consisting of herb species grown with either a grass species or a grass and legume (multispecies swards) were compared with non-herbcontaining swards consisting of a grass species grown as a monoculture or grass-legume swards (simple swards). A literature search was completed using the online databases CAB Direct, Web of Science, and Google Scholar, using the search strategy "dairy cow", "herb OR forb OR phorb", and "grazing". Milk production data, variance, and sample size were required for eligibility. In all, 116 studies were identified. Following eligibility screening, 11 papers from 6 journals, published between 2006 and 2018, were available for analysis. Studies were from New Zealand $(\mathrm{N}=7)$, Australia $(\mathrm{N}=3)$, and the United States $(\mathrm{N}=1)$. The population was either Holstein Friesian or Holstein Friesian $\times$ Jersey dairy cows, with a range in mean daily milk yield (MY) from $12.1 \mathrm{~kg}$ to $34.7 \mathrm{~kg}$ (mean $=18.6 \mathrm{~kg})$. A total of $25 \mathrm{com}-$ parisons were used for milk production analysis, with 324 and 284 cows included in multispecies and simple sward groups respectively. Data analysis was conducted in $\mathrm{R}$ using a random effects, robust variance estimation model (R Foundation for Statistical Computing, Vienna, Austria). Heterogeneity was reported using the $I^{2}$ statistic. Milk production was significantly increased. Analysis of MY resulted in a weighted mean difference $(\mathrm{WMD})$ of $+1.20 \mathrm{~kg} / \mathrm{d}\left(95 \% \mathrm{CI}=0.90,1.49 ; I^{2}=4 \%\right)$. Fat and protein $\mathrm{kg}$ were also significantly increased $(\mathrm{WMD}+0.06 \mathrm{~kg} / \mathrm{d} ; \mathrm{CI}=0.01,0.11)$. Urinary nitrogen excretion was estimated from milk urea nitrogen when reported $(\mathrm{n}=6)$. A WMD of $-28.1 \mathrm{~g}$ of $\mathrm{N} / \mathrm{d}(95 \% \mathrm{CI}$ $=-81.1,24.9)$ was generated, with heterogeneity high
\end{abstract}

Received June 7, 2019.

Accepted October 8, 2019.

*Corresponding author: kate.mc-carthy.2@ucdconnect.ie among studies $\left(I^{2}=75 \%\right)$. This meta-analysis shows the potential benefits of multispecies swards. Although we saw no significant difference in UN excretion, an increase in milk production was found.

Key words: herb species, dairy cow, milk production, nitrogen excretion

\section{INTRODUCTION}

Pasture-based dairy production is the primary system of dairy farming in temperate countries, including Ireland and New Zealand, providing a unique competitive advantage to producers (Ryan et al., 2011). However, the environmental impact of dairy systems is a growing issue, with nitrogen $(\mathrm{N})$ losses from dairy systems a cause for concern. As a result, interest has increased in potential measures to reduce $\mathrm{N}$ losses while maintaining milk production (Spek et al., 2013). Dairy cows are poor utilizers of $\mathrm{N}$, with $\mathrm{N}$ use efficiency reported between 21 and 42\% (Whelan et al., 2013). A large proportion of the $\mathrm{N}$ ingested by grazing animals is excreted back onto the soil in the small concentrated areas of urine and dung patches (Cameron et al., 2013), leading to a large surplus of $\mathrm{N}$ on pasture (Romera et al., 2017). Urea is the main $\mathrm{N}$ component in urine (50 to 90\%; Fadul-Pacheco et al., 2017) and is associated with $\mathrm{N}$ losses through ammonia $\left(\mathrm{NH}_{3}\right)$ volatilization, nitrate leaching, and dissipation of $\mathrm{N}$ as nitrous oxide $\left(\mathrm{N}_{2} \mathrm{O}\right)$, nitric oxide (NO), and nitrogen dioxide gas $\left(\mathrm{NO}_{2}\right.$; de Vries et al., 2001).

Grazed forage is the primary constituent of dairy cow diets in pasture-based systems. Interest has increased in the potential role of alternative plant species in altering $\mathrm{N}$ intake of dairy cows (Beukes et al., 2014) and ultimately reducing $\mathrm{N}$ losses from dairy farming. Nitrogen intake has been shown to have a positive linear relationship with urine, fecal, and milk $\mathrm{N}$ excretion in grazing dairy cows (Mulligan et al., 2004). The inclusion of herb species such as chicory (Cichorium intybus L.) and ribwort plantain (Plantago lanceolata L.) in grazing swards, hereafter called multispecies swards, has been 
shown to reduce urinary nitrogen (UN) excretion (Bryant et al., 2017; Dodd et al., 2018). In addition, the DM yields from multispecies swards containing perennial ryegrass (PRG; Lolium perenne L.), white clover (WC; Trifolium repens L.), and herb species have proven to be comparable with PRG and PRG-WC grazing swards, hereafter called simple swards, with lower fertilizer $\mathrm{N}$ inputs required (Finn et al., 2013; Grace et al., 2018).

The successful integration of new technologies on farms is influenced by the relative economic advantage they provide (Pannell et al., 2006). A lack of clear economic gains of multispecies swards over traditional PRG or PRG-WC swards could impair their adoption on farms (Romera et al., 2017). Therefore, it is of interest to investigate the effects of multispecies swards containing herbs on milk production in grazing dairy cows. Previous reviews have examined the potential of multispecies swards in grazing ruminant systems. Romera et al. (2017) assessed the potential of multispecies swards in dairy farm systems through the integration of research data into a whole-farm model, and Cranston et al. (2015) reviewed the role of multispecies swards for sheep and beef production. An extensive review by Vibart et al. (2016) assessed literature comparing simple and multispecies swards on aspects of soil-plant-animal interrelationships related to $\mathrm{N}$ leaching losses. However, knowledge gaps have yet to be addressed. Are $\mathrm{N}$ mitigation effects due to species functionality rather than sward diversity (Box et al., 2017)? What are the optimum species composition and management practices to sustain sward composition and functionality (Grace et al., 2018)? And what is the potential of multispecies swards for milk production (Chapman et al., 2008)?

We hypothesized that the inclusion of herb species in grazing swards for lactating dairy cows would result in a reduction in urinary nitrogen excretion while maintaining or increasing milk production compared with conventional grass or grass and legume swards. To investigate this, we carried out a systematic review and meta-analysis. A meta-analysis represents a quantitative approach to combining information from multiple studies (McAloon et al., 2016), with the benefit of being able to combine a large, complex, and sometimes conflicting body of literature (Lean et al., 2009) to generate an effect estimate. Combining data from different studies results in increased statistical power, making it easier to detect differences (Rosenberg et al., 2004). Forecasting and decision-support software and research stakeholders all require quantitative data, such as that generated from a meta-analysis, to allow for better precision of estimates and improved knowledge of animal responses to treatments (Sauvant et al., 2008).

\section{MATERIALS AND METHODS}

A systematic review and meta-analysis were conducted to investigate the effect of multispecies swards on milk production and UN excretion. The objective of this analysis was to estimate the effect of multispecies swards on milk production and UN excretion, and to quantify the optimum level of herb inclusion in a multispecies sward to maintain sward functionality and species composition.

The population was defined as lactating dairy cows. The intervention for review was a multispecies grazing sward, consisting of an herb species grown either with a grass species or with a grass and a legume. The comparator was a non-herb-containing grazing sward consisting of a grass species grown as a monoculture or grown with a legume. The primary outcome of interest was milk yield (MY). Other outcomes, such as UN, DMI, and sward nutritive characteristics, were extracted when reported.

\section{Literature Search}

A literature search was conducted using the online databases CAB Direct, Web of Science, and Google Scholar. The search strategy used included "dairy cow", "herb OR forb OR phorb", and "grazing". For the purposes of this review, peer-reviewed literature was considered as the minimum reporting standard required for inclusion. Reference lists from papers were reviewed for any additional studies relevant to the review. Reporting was carried out according to guidelines set out in the PRISMA statement (Moher et al., 2009).

\section{Eligibility Criteria}

Studies were initially screened by title and abstract. They were included for further screening if (1) the study was reported in English; (2) the population in the study was dairy cows; and (3) the treatment of interest included at least 1 herb species offered as fresh forage through grazing or zero grazing, with either a grass species or a grass and a legume.

\section{Eligibility Screening}

Studies were further screened for inclusion based on the materials and methods used. Authors were contacted where papers were not available for access (N $=1$ ). Studies must have reported a mean effect, variance, sample size, and milk yield. Data must be original and not reported in a previous or subsequent study. An obvious attempt to address confounding factors in 
the data analysis was required (e.g., blocking of sample population, randomization). Studies with inadequate methodologies or reporting were excluded.

\section{Data Extraction}

Information on study and production characteristics was extracted according to Table 1. Data from studies was standardized to the same unit according to Table 1. Data on forage nutrient characteristics was also extracted. Variance estimates were converted to standard deviation (SD) for all studies according to formulae outlined in the Cochrane Handbook (Higgins and Green, 2011). Standard error of the mean (SEM) was converted to SD using the formula $S D=S E \times \sqrt{N}$, and standard error of the difference (SED) was converted according to the equation $S D=\frac{S E}{\sqrt{\frac{1}{N_{E}}+\frac{1}{N_{C}}}}$, where $N_{E}$ refers to the sample size of the experimental group and $N_{C}$ refers to the sample size of the control group. For studies that reported a least significant difference (LSD) value, $P$-values were converted to $T$-values. These were then used to generate a SED and input into the formula above. Where levels of significance were reported $(P<0.05, P<0.001), P$ was assumed to be equal to the level of significance given. Multi-intervention studies $(\mathrm{N}=2)$ were merged to avoid double counting of control groups.

Energy-corrected milk was calculated according to the formula $(0.3273 \times \mathrm{MY} \mathrm{kg})+(7.65 \times$ protein $\mathrm{kg})+$ $(12.97 \times$ fat kg; Tyrrell and Reid, 1965). Daily fat and protein yields $(\mathrm{kg})$ were estimated, where possible, from studies that reported MY $(\mathrm{kg} / \mathrm{d})$ and fat and protein $\%$ $(\mathrm{N}=5)$. When reported, MUN values given as mmol/L were converted to milligrams per deciliter $(\mathrm{mg} / \mathrm{dL})$ using the equation MUN mmol/L $=(M U N \mathrm{mg} / \mathrm{dL} \times 10$
$\mathrm{dL} / \mathrm{L}) / 28 \mathrm{~g}$ of $\mathrm{N}$. Urinary nitrogen excretion ( $\mathrm{g}$ of $\mathrm{N} / \mathrm{d}$ ) was then estimated using the equation $37+12.33 \times$ MUN mg/dL (Spek et al., 2013).

\section{Data Analysis}

Extraction of the study data demonstrated that often more than 1 comparison was reported from an individual study. The data in this analysis were gathered from the same individuals at several time points over an experimental period (i.e., repeated measures) and were therefore not statistically independent. The data were deemed to have a hierarchical structure, in which observations are not mutually independent but instead have a higher correlation structure due to the nature of the experimental design (Bello et al., 2016).

To account for the dependence within studies, a robust variance estimation method was used to analyze the data (Hedges et al., 2010). This method has the advantage of not requiring knowledge of the underlying covariance structure (Tanner-Smith and Risser, 2016). Data analysis was conducted though RStudio (1.1.463; R Foundation for Statistical Computing, Vienna, Austria) using the package "robumeta," with random effects models fitted using the "robu" function. A random effect meta-analysis allows the effect of herb species inclusion on outcomes of interest (e.g., MY, DMI) to vary for each study (McAloon et al., 2016). Studies were weighted according to the correlated effects model, which assumes that dependence arises from measurements made on the same number of subjects (Fisher and Tipton, 2015).

For the regression model, the weighted mean difference (WMD) was calculated using the robust regression models developed by Hedges et al. (2010). When the regression model has only an intercept $b 1$, the weighted mean has the following form:

Table 1. Data extracted from included studies investigating the effect of herb species inclusion on milk yield ${ }^{1}$

\begin{tabular}{|c|c|c|c|}
\hline Study characteristic & Outcomes extracted & Statistical characteristic & Dietary characteristic \\
\hline
\end{tabular}

${ }^{1} \mathrm{UN}=$ urinary nitrogen excretion $(\mathrm{g}$ of $\mathrm{N} /$ day); $\mathrm{SED}=$ standard error of the difference; OMD = organic matter digestibility; WSC $=$ watersoluble carbohydrates. 


$$
b 1=\frac{\sum_{j=1}^{m} \Sigma_{i=1}^{k 1} w i j \mathbf{T} i j}{\sum_{j=1}^{m} \sum_{i=1}^{k 1} w i j},
$$

where $m$ is the total number of studies, $k$ is the total number of comparisons, wij is the weighting for comparisons within experiments, and $\mathbf{T} i j$ is the vector of the ES estimates of comparisons within experiments (Lean et al., 2019). If all estimates are given identical weights, as described in Hedges et al. (2010), the robust variance estimate is reduced to the following:

$$
v^{R}=\frac{\sum_{j=1}^{m} w_{j}^{2}(\breve{\mathrm{T}} j-b 1)^{2}}{\left(\sum_{j=1}^{m} w_{j}\right)^{2}},
$$

where $\breve{\mathrm{T}} j$ is the unweighted mean of the estimates in the $j$ th cluster, $b 1$ is the estimate of the weighted mean, and $w_{j}$ is the total weight given to estimates in the $j$ th cluster. This is a kind of weighted variance, which reduces to $(m-1) / m^{2}$ times the usual variance when the weights are identical and (because $\mathrm{r}=1$ in this case), the robust standard error of regression equals $1 / m$ times the usual variance of $\breve{\mathrm{T}} j$ when the weights are equal.

Results were reported as the WMD between groups. Heterogeneity between studies was estimated using the Higgins $I^{2}$ statistic. The $I^{2}$ statistic indicates the proportion of total variation in the treatment effect estimates that is due to heterogeneity between studies (Higgins and Thompson, 2002). It is expressed as a percentage, with a lower $I^{2}$ value allowing greater confidence in the overall WMD. The $I^{2}$ can be interpreted as follows: 0 to $40 \%$ might not be important, 30 to $60 \%$ may show moderate heterogeneity, 50 to $90 \%$ can indicate substantial heterogeneity, and 75 to $100 \%$ shows considerable heterogeneity (Higgins and Green, 2011).

Initial analysis compared multispecies swards to simple swards. Subsequent subgroup analysis was carried out to investigate heterogeneity and assess the effect of the herb used, with studies grouped according to chicory, plantain, or both. Finally, meta-regression analysis was conducted to investigate the optimum percentage of herb in the sward, with models constructed for MY and UN. In the initial analysis, the mean difference, which was calculated as the difference between multispecies and simple sward means, was included in an intercept-only model. Covariates of interest were subsequently added to the model in a stepwise fashion in further analyses. Small-sample corrections were fitted as described in Tipton (2015). For subgroup analysis, group mean and center were included in the model according to the method outlined in Fisher and Tipton
(2015) to assess whether subgroup effects were significant at study level $(P<0.05)$ or at mean difference level before further analysis was carried out.

Forest plots were generated using the $\mathrm{R}$ package "meta" (Schwarzer, 2007). Funnel plots were constructed to test for publication bias within included studies. Egger's test was used to test for funnel plot asymmetry (Egger et al., 1997).

\section{RESULTS}

\section{Study Selection}

In total, 116 studies were identified after the literature search. Of these, 114 were found after database searching, and an additional 2 were included after manually searching the reference lists of papers. Figure 1 shows a PRISMA flowchart detailing the literature search and study collection process (Moher et al., 2009). When duplicates were removed, 75 studies remained. After screening studies by title and abstract, 57 studies were removed.

Eighteen studies were presented for eligibility screening. Of these, 7 failed the eligibility criteria. One study was excluded because data were subsequently published in a different study $(\mathrm{N}=1)$. Another study was excluded from the final analysis because MY was not the focus of the investigation $(\mathrm{N}=1)$. Studies were also excluded for failing to clearly report MY $(\mathrm{N}=1)$ or sample size $(\mathrm{N}=1)$. Three studies were excluded because they were not peer-reviewed $(\mathrm{N}=3)$. The final list contained 11 studies and 25 comparisons, from 6 journals published between 2006 and 2018 (Table 2). Studies were from New Zealand $(\mathrm{N}=7)$, Australia (N $=3)$, and the United States $(\mathrm{N}=1)$. A total of 324 and 284 cows were in multispecies and simple sward groups, respectively. All studies included in the final analysis were randomized and contained continuous data. Three of the studies included in this analysis were pseudo-replicated, with the remaining studies including replicated grazing herds $(\mathrm{N}=6)$, measurement periods $(\mathrm{N}=1)$, or grazing seasons $(\mathrm{N}=1)$.

The dairy cow populations in each study were either Holstein Friesian $(\mathrm{N}=4)$ or Holstein Friesian $\times$ Jersey $(\mathrm{N}=9)$. Swards were grazed by cows in 10 studies, and zero grazed and offered to housed cows in 1 study (Minneé et al., 2017). Three studies fed concentrates during the experiment, with daily supplementation ranging from 2 to $9.2 \mathrm{~kg}$ per cow. Comparisons included in the final table for analysis were from all stages of lactation. Early- $(\mathrm{N}=5)$, mid- $(\mathrm{N}=9)$, and late-lactation cows $(\mathrm{N}=11)$ averaged 67,111 , and 215 DIM, respectively.

Multispecies swards contained either chicory $(\mathrm{N}=4)$ or ribwort plantain $(\mathrm{N}=2)$ or both $(\mathrm{N}=5)$. Control 


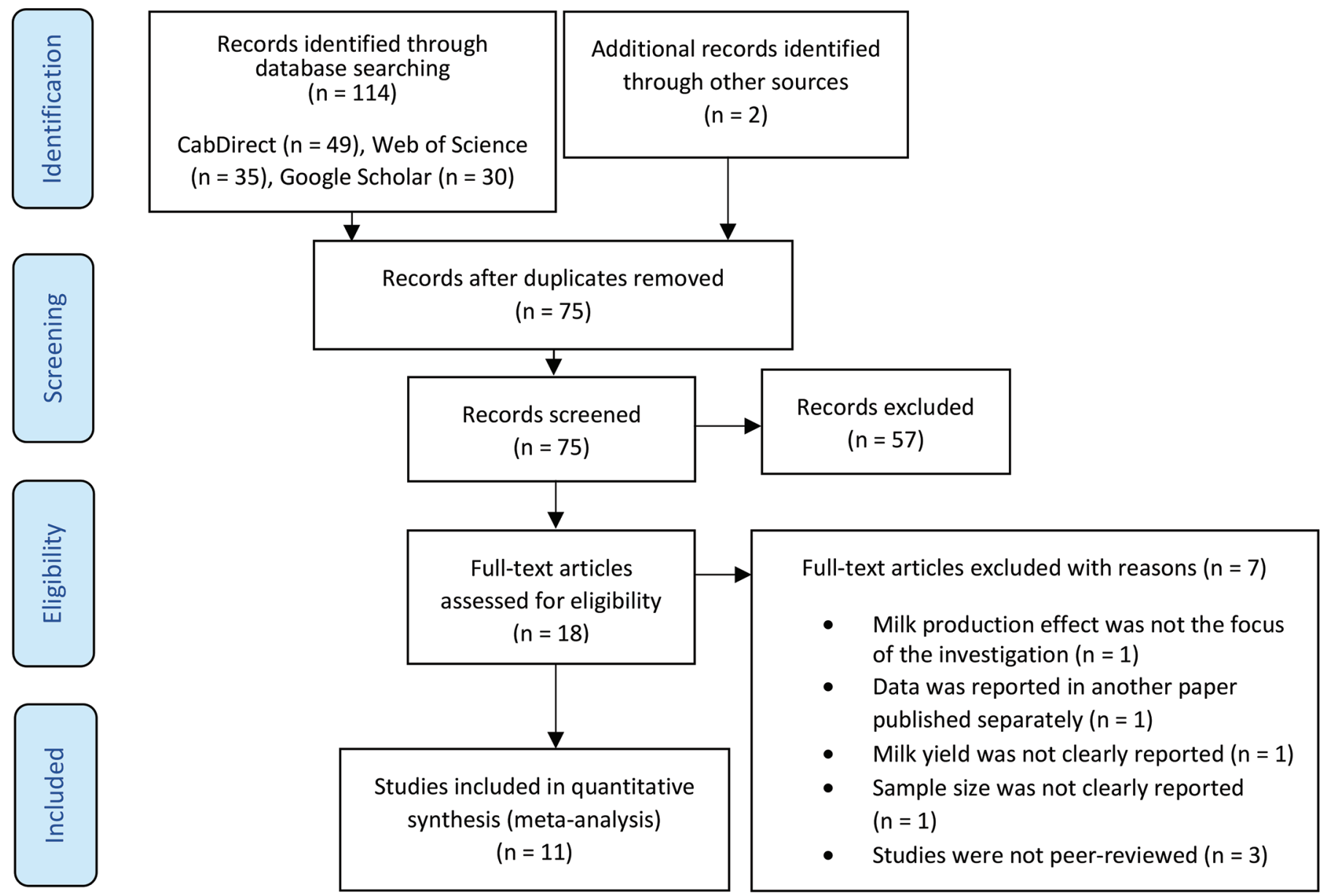

Figure 1. A PRISMA flowchart detailing the literature search and study collection process (Moher et al., 2009).

swards that contained a legume $(\mathrm{N}=8)$ consisted of WC $(\mathrm{N}=7)$, or lucerne (Medicago sativa $\mathrm{L}$.; $\mathrm{N}=1$ ). A variety of grass species were included in the 25 comparisons, including PRG $(\mathrm{N}=14)$, tall fescue (Festuca arundinacea L.; $\mathrm{N}=6$ ), high-sugar PRG $(\mathrm{N}=3)$, orchardgrass (Dactylis glomerata L.; $\mathrm{N}=1$ ), and Italian ryegrass (Lolium multiflorum $\mathrm{L} . ; \mathrm{N}=1$ ).

\section{Risk of Bias}

Publication bias within studies that investigated the effect of multispecies swards on MY was assessed using a funnel plot (Figure 2). Egger's test for plot asymmetry was non-significant $(P=0.51)$, indicating an absence of publication bias.

\section{Multispecies Versus Control Sward}

Initial analysis compared multispecies swards to simple swards. Forest plots were constructed for all outcomes listed in Table 1. Results, including WMD,
$I^{2}$, confidence intervals, and sample size, are presented in Table 3. Our analysis showed no significant difference between multispecies and simple swards for DMI, MUN, UN excretion, or the concentration of fat, protein, and lactose in milk.

\section{Milk Production}

A WMD of $+1.20 \mathrm{~kg} / \mathrm{d}(95 \% \mathrm{CI}=0.90,1.49)$ was observed between multispecies and simple swards for MY (Figure 3). Little or no variability was observed between studies $\left(I^{2}=4 \%\right)$. For ECM, a WMD of +1.30 $\mathrm{kg} / \mathrm{d}(95 \% \mathrm{CI}=0.74,1.86 ; P<0.01)$ was found, with moderate heterogeneity between studies $\left(I^{2}=47 \%\right)$. In addition, a modest increase in daily fat in kilograms $(\mathrm{WMD}=+0.04 \mathrm{~kg} / \mathrm{d} ; 95 \% \mathrm{CI}=0.00,0.08 ; P<0.05)$ and protein in kilograms $(\mathrm{WMD}=+0.05 \mathrm{~kg} / \mathrm{d} ; 95 \%$ CI $=0.03,0.07 ; P<0.01)$ was observed, with $I^{2}=78 \%$ for both outcomes. Combined fat and protein $\mathrm{kg}$ production increased significantly $(\mathrm{WMD}=0.06 \mathrm{~kg} / \mathrm{d} ; 95 \%$ CI $=0.01,0.11 ; P<0.05)$, with little heterogeneity found 
between studies $\left(I^{2}=26 \%\right)$. These results indicate that dairy cows grazing multispecies swards had increased milk production, with milk fat and protein production increasing concurrently with MY.

\section{Subgroup Analysis}

Studies were subgrouped by herb to assess whether any one herb had a greater effect on daily MY than the other (Figure 4). Subgroups included chicory $(\mathrm{N}=5)$, plantain $(\mathrm{N}=6)$, or both $(\mathrm{N}=14)$. Further analysis showed that studies containing both reported a significantly higher MY compared with studies containing chicory or plantain only $(P=0.04 ; \mathrm{WMD}=1.23 \mathrm{~kg} / \mathrm{d}$; $95 \%$ CI $=0.16,2.31$ ). However, the degrees of freedom (df) for this estimate was 1.75. The df in this analysis were estimated using a Satterthwaite approximation, which holds when df are greater than or equal to 4 . When $\mathrm{df}<4$, the approximation does not hold, and the type I error can be larger than the stated $P$-value associated with the test (Tanner-Smith et al., 2016).

Subgrouping by stage of lactation was also carried out. Studies were grouped according to early $(\mathrm{n}=5)$, mid $(\mathrm{n}=9)$, and late lactation $(\mathrm{n}=11$; Figure 5$)$. Although an overall increase in MY was found, when studies were compared according to stage of lactation there was no significant difference in MY between multispecies and simple swards.

Additional analysis, in which studies were grouped according to the composition of the control sward (i.e., simple sward), was undertaken to assess whether the inclusion of a legume influenced milk production more than did the inclusion of herb species. Subgroups consisted of grass and grass + legume. The composition of the control sward had no effect on MY or daily fat and protein yield.

\section{Meta-Regression Analysis}

Meta-regression analysis was carried out to investigate the effect of percentage of herb species inclusion in a grazing sward on daily MY and UN excretion. Metaregression explores whether a linear association exists between variables (MY and UN) and a comparative treatment effect (multispecies sward), along with the direction of that association (Baker et al., 2009). The percentage of herb in the multispecies swards ranged from 9 to $54 \%$, with herb composition averaging $35.8 \%$ of swards.

A positive relationship was found between daily MY and the percentage of herb in the sward with the equation $\mathrm{MY}=0.88+0.08($ Herb \%) generated after

Table 2. Summary of experiment comparisons and sample size (no.) used in the meta-analysis investigating the effect of herb species inclusion on milk yield ${ }^{1}$

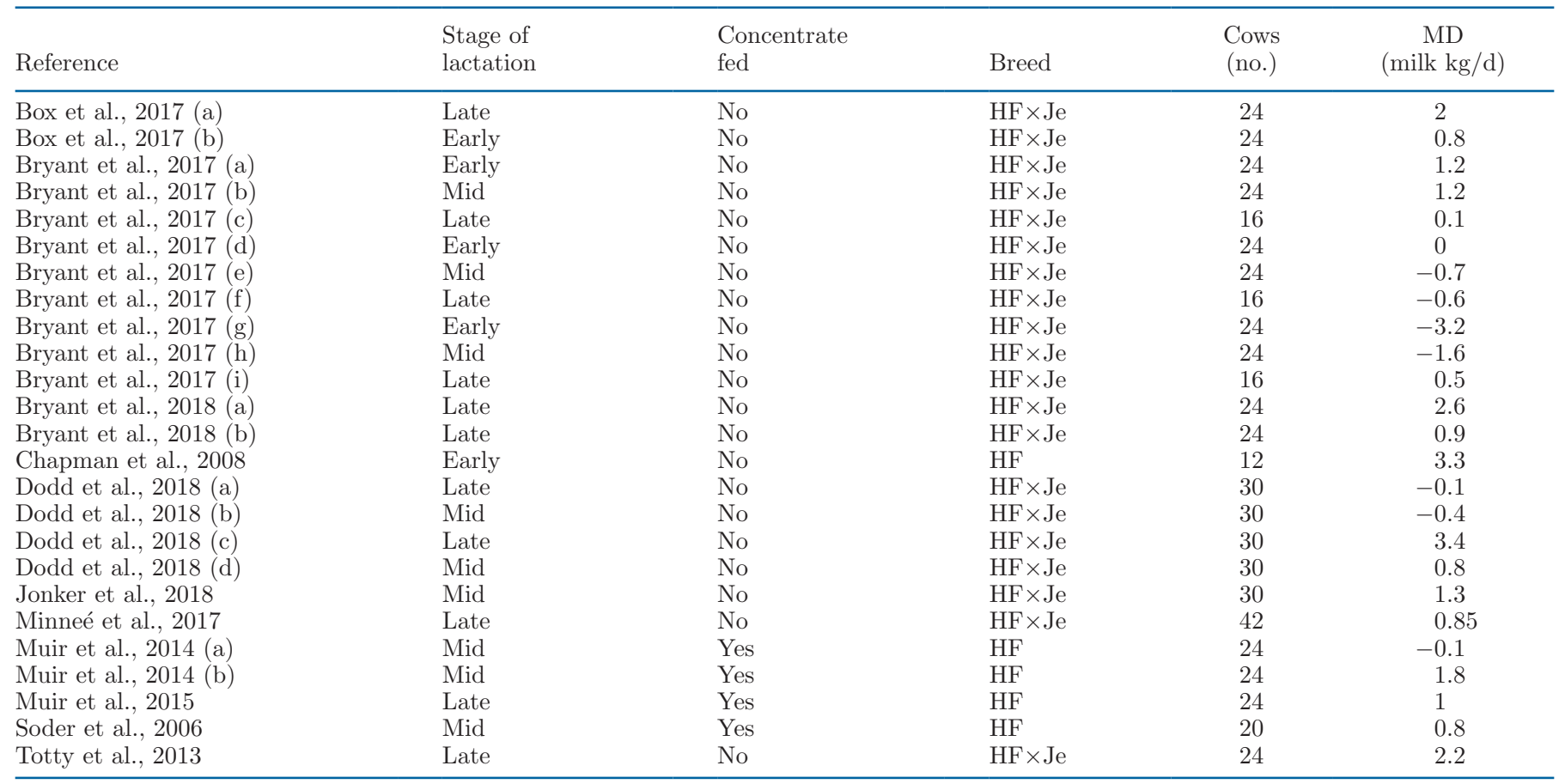

${ }^{1}$ Studies are listed by first author's name and year, with multiple comparisons from the same study indicated by alphabetical notation in parentheses. Mean difference (MD) refers to the difference in mean milk yield between multispecies and simple sward groups in milk $\mathrm{kg} / \mathrm{d}$. Breed includes Holstein Friesian $(\mathrm{HF})$ or Holstein Friesian $\times$ Jersey cross $(\mathrm{HF} \times \mathrm{Je})$ cows. 
analysis. However, this relationship was non-significant $(P=0.21)$. A negative association was seen between UN excretion and the \% herb in the sward, such that UN g/d $=56.05$ to 2.32 (Herb \%). Similarly, this association was not statistically significant $(P=0.27)$.

\section{Sward Nutritive Characteristics}

Sward nutritive values for DM, CP, ADF, NDF, water-soluble carbohydrates, and OM digestibility were extracted. Table 4 shows the WMD, $I^{2}$ and $95 \%$ confidence interval for each forage nutritive characteristic extracted. Multispecies swards had significantly lower DM and NDF compared with simple swards. Multispecies swards also tended to have lower ADF in comparison to simple swards $(P=0.07)$, indicating the digestible nature of multispecies swards. There was no significant difference in $\mathrm{CP}$, water-soluble carbohydrates, or $\mathrm{OM}$ digestibility between swards.

Studies were separated according to stage of lactation to assess seasonal differences in sward nutritive characteristics (Table 5). Due to the low number of comparisons available for some outcomes, these data were not statistically analyzed. However, OM digestibility is numerically higher for both multispecies and simple swards in the early-lactation group compared with mid and late lactation. The trend in CP concentration was similar in both multispecies and simple swards. Crude protein increases when progressing from early to mid and late lactation, with late lactation having the highest $\mathrm{CP}$ value.

\section{DISCUSSION}

The equivocal nature of the evidence surrounding the potential role of multispecies swards in dairy systems lends itself to conducting a meta-analysis to assess the potential role of multispecies swards in dairy systems. To our knowledge, no previously published reviews (1) review the available literature on studies that investigate the effect of multispecies swards on milk yield and (2) quantify the effect of multispecies swards on UN excretion from lactating dairy cows. Our results have enabled us to address the objectives previously outlined in the introduction, which were, ultimately, to estimate the effect of multispecies swards on milk production and UN excretion. Because agriculture is considered the sector with the largest nitrogen reduction potential within the EU (EUC, 2017), information on sward performance and management, and dairy cow milk production and nitrogen excretion while grazing multispecies swards, may prove valuable as measures to reduce nitrogen losses from dairy production are explored.

After an extensive literature search, 11 studies were included in the final analysis. No publication bias was evident in the funnel plot used to test studies investigating milk yield (Figure 2), and heterogeneity was

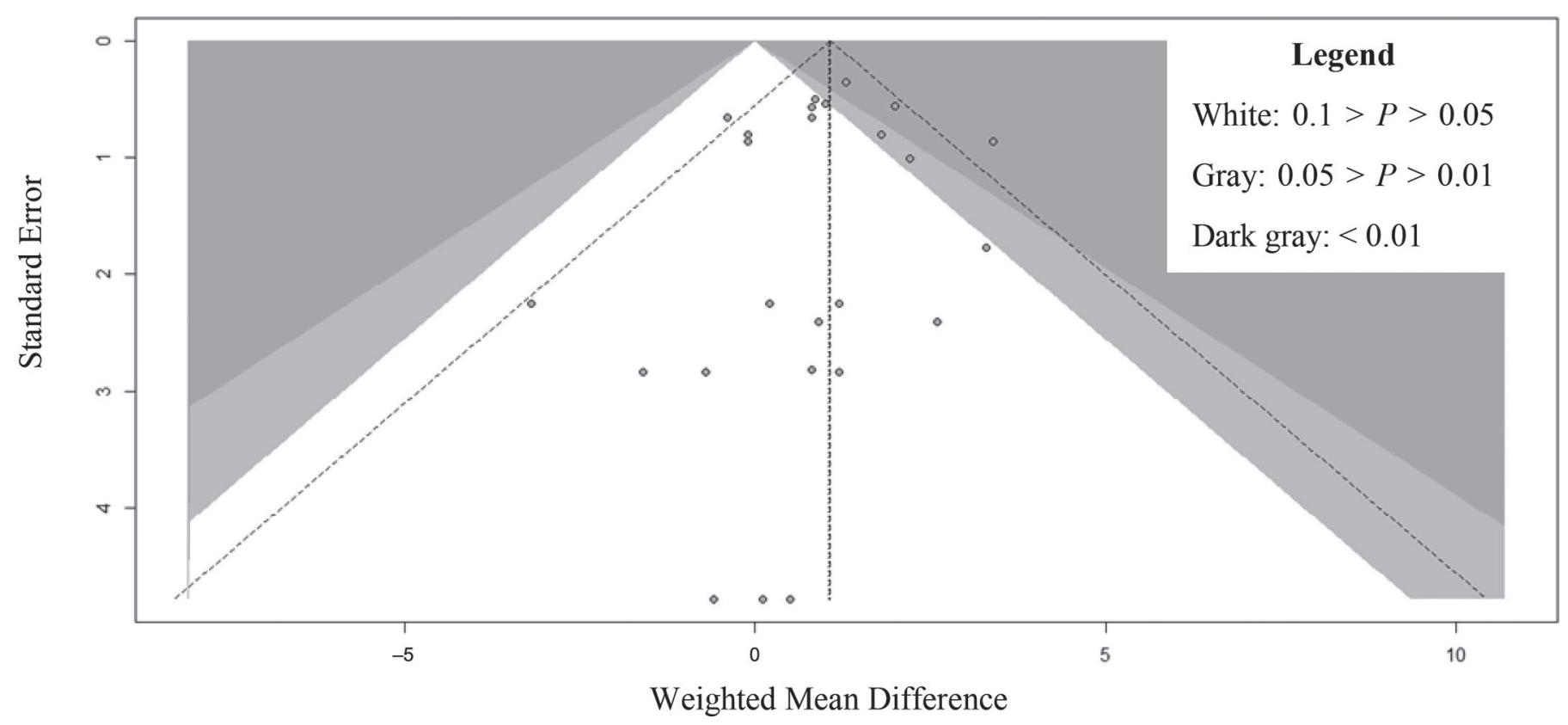

Figure 2. A contour-enhanced funnel plot to test for publication bias within included studies that investigated the effect of herb species inclusion on daily milk yield. The contour lines correspond to statistical significance $(P=0.01,0.05$, or 0.1$)$ and help differentiate asymmetry caused by publication bias from that caused by other factors (Lean et al., 2009). 


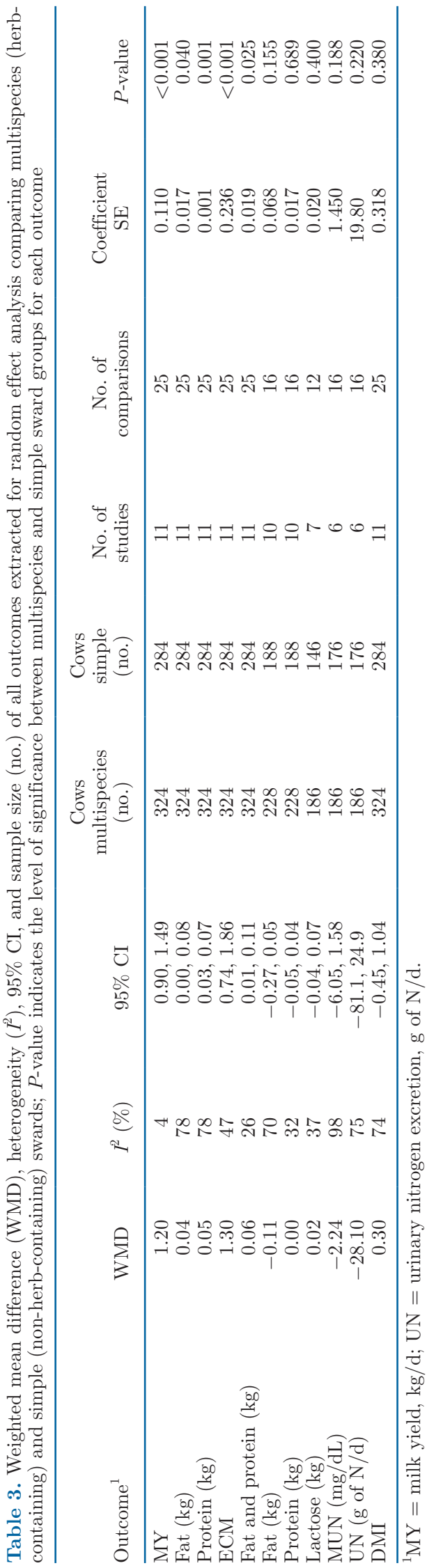

low between studies $\left(I^{2}=4 \%\right)$. However, a total of 11 studies, enabling 25 comparisons, provides limited power to evaluate our hypothesis. The absence of studies conducted in Europe highlights the need for further research in this area among European institutions.

\section{Milk Production}

Initial analysis in this study found that multispecies swards increased daily MY by $1.20 \mathrm{~kg} / \mathrm{d}$. Increased MY for cows grazing multispecies swards has been found in studies conducted in France (Roca-Fernández et al., 2016), New Zealand (Bryant et al., 2018), and Australia (Chapman et al., 2008). However, other studies from New Zealand and Australia reported no effect of sward type on milk production (Muir et al., 2014; Dodd et al., 2018). Our analysis showed an increase in milk component yield for cows grazing multispecies swards, with ECM, fat $(\mathrm{kg})$, protein $(\mathrm{kg})$, and combined fat and protein $(\mathrm{kg})$ all increasing significantly. An increase in milk components has previously been reported for cows grazing swards containing plantain (Pembleton et al., 2016) and chicory (Roca-Fernández et al., 2016).

Similar to our results, increased DMI on multispecies swards has not always been reported concurrently with increased MY. Differences in apparent intake between treatments would help explain differences in milk production (Box et al., 2017). However, we found no difference in overall DMI between treatments. Our analysis showed that multispecies swards had significantly lower NDF compared with simple swards (Table 4). Furthermore, ADF concentration tended to be lower in multispecies swards. These differences in nutrient concentration may have influenced the milk production response of dairy cows consuming these swards. Selective grazing of digestible herb species in multispecies swards may result in the ingestion of less fiber, which could influence MY. Although selective grazing was not investigated in this analysis, it may be a factor in the improvement of MY. Grace et al. (2018) theorized that preferential selection of herbs by sheep accounted for the differences in botanical composition between years in their study. In dairy cows, Soder et al. (2006) suggested that animals favored grazing the young leaf growth of chicory, whereas cows have also been reported to select plantain in early and mid lactation (Pembleton et al., 2016).

A cautious subgroup analysis estimate $(\mathrm{df}<4)$ indicated that swards containing both chicory and plantain resulted in significantly higher MY compared with those containing either chicory or plantain only. Studies containing both herbs were conducted in early $(\mathrm{N}=3)$, mid $(\mathrm{N}=4)$, and late $(\mathrm{N}=5)$ lactation. Differences in herbage nutritive value may be a plausible factor in 
the differences in milk production between treatments (Muir et al., 2015). Despite no significant difference in MY between the stages of lactation, extraction of sward nutritive value did highlight seasonal differences between multispecies and simple swards. Increasing the number of species in a sward can result in greater forage availability, as complementarity of timings of growth of different species may reduce the effect of the seasonality of supply of herbage (Grace et al., 2018). Increased species diversity can also prolong and improve nutrient supply to the grazing animal, particularly through a re- duction in NDF concentration (Pembleton et al., 2015). However, the benefits of increasing pasture species is only realized up to an optimum, with Sanderson et al. (2005) reporting no difference in DM yield between a 3-, 6-, or 9-species mixture, although all mixtures produced more DM than did the control grass-legume mixture.

Dodd et al. (2018) identified an unresolved question, asking whether effects of multispecies swards on MY and UN excretion are due to species diversity within a grazing sward or to the functionality of the species

\section{Study}

Box et al, 2017a

Box et al, 2017b

Bryant et al, 2017a

Bryant et al, 2017b

Bryant et al, 2017c

Bryant et al, 2017d

Bryant et al, 2017e

Bryant et al, 2017f

Bryant et al, 2017g

Bryant et al, 2017h

Bryant et al, 2017i

Bryant et al, 2018a

Bryant et al, 2018b

Chapman et al, 2008

Dodd et al, 2018a

Dodd et al, 2018b

Dodd et al, 2018c

Dodd et al, 2018d

Jonker et al, 2018

Minnee et al, 2017

Muir et al, 2014a

Muir et al, 2014b

Muir et al, 2015

Soder et al, 2006

Totty et al, 2013
MD $\quad 95 \% \mathrm{Cl}$

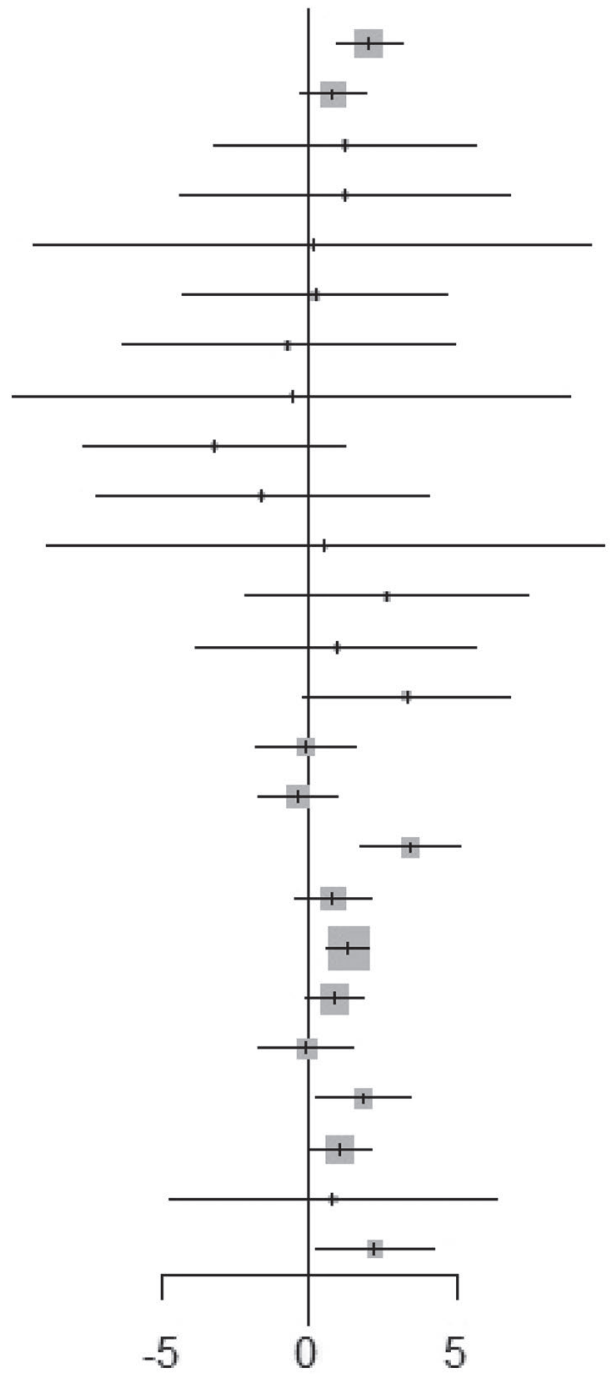

$2.00[0.91 ; 3.09]$

$0.80[-0.32 ; 1.92]$

$1.20[-3.21 ; 5.61]$

$1.20[-4.37 ; 6.77]$

$0.10[-9.27 ; 9.47]$

$0.20[-4.21 ; 4.61]$

$-0.70[-6.27 ; 4.87]$

$-0.60[-9.97 ; 8.77]$

$-3.20[-7.61 ; 1.21]$

$-1.60[-7.17 ; 3.97]$

$0.50[-8.87 ; 9.87]$

$2.60[-2.11 ; 7.31]$

$0.90[-3.81 ; 5.61]$

$3.30[-0.17 ; 6.77]$

$-0.10[-1.79 ; 1.59]$

$-0.40[-1.69 ; 0.89]$

$3.40[1.71 ; 5.09]$

$0.80[-0.49 ; 2.09]$

$1.30[0.61 ; 1.99]$

$0.85[-0.12 ; 1.82]$

$-0.10[-1.67 ; 1.47]$

$1.80[0.23 ; 3.37]$

$1.00[-0.06 ; 2.06]$

$0.80[-4.72 ; 6.32]$

$2.20[0.23 ; 4.17]$

Figure 3. Forest plot of the difference in means (MD) between multispecies and simple swards and 95\% CI of daily milk yield (MY) for studies that investigated the effect of herb species inclusion in a grazing sward for lactating dairy cows on MY (kg/d). Studies are listed by first author's name and year, with multiple comparisons from the same study indicated by alphabetical notation. The MD of each comparison is represented by a square on each line. The line connected to each square indicates the $95 \%$ CI of the MD. Relative weighting of each comparison is represented by the gray box surrounding the MD, with larger squares representing greater weight. An MD to the left of the vertical line represents a reduction in the outcome, whereas an MD to the right of the line indicates an increase in the outcome of interest. 
Study

Herb $=$ Both

Bryant et al, 2017a

Bryant et al, 2017b

Bryant et al, 2017c

Bryant et al, 2017d

Bryant et al, 2017e

Bryant et al, 2017f

Bryant et al, 2017g

Bryant et al, 2017h

Bryant et al, 2017i

Bryant et al, 2018a

Bryant et al, 2018b

Jonker et al, 2018

Minnee et al, 2017

Totty et al, 2013

Herb $=$ Chicory

Chapman et al, 2008

Muir et al, 2014a

Muir et al, 2014b

Muir et al, 2015

Soder et al, 2006

Herb = Plantain

Box et al, 2017a

Box et al, 2017b

Dodd et al, 2018a

Dodd et al, 2018b

Dodd et al, 2018c

Dodd et al, 2018d

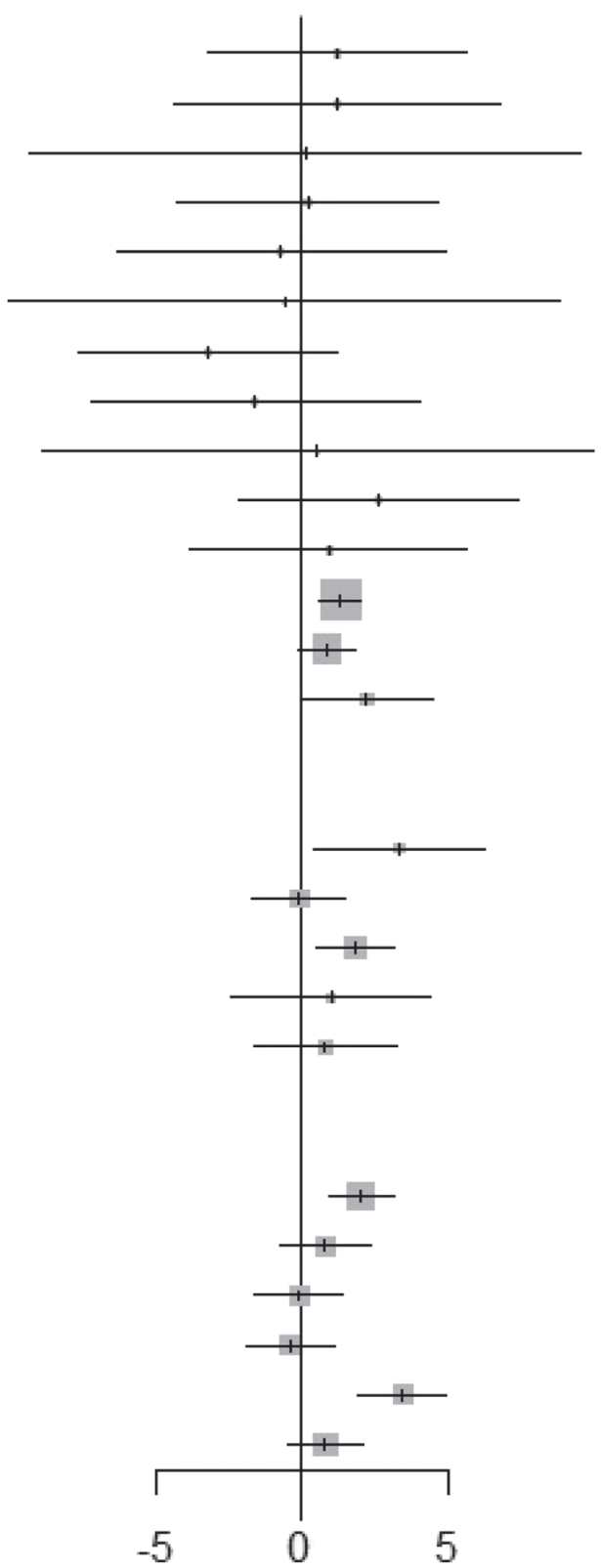

$1.20[-3.21 ; 5.61]$

$1.20[-4.37 ; 6.77]$

$0.10[-9.27 ; 9.47]$

$0.20[-4.21 ; 4.61]$

$-0.70[-6.27 ; 4.87]$

$-0.60[-9.97 ; 8.77]$

$-3.20[-7.61 ; 1.21]$

$-1.60[-7.17 ; 3.97]$

$0.50[-8.87 ; 9.87]$

$2.60[-2.11 ; 7.31]$

$0.90[-3.81 ; 5.61]$

$1.30[0.61 ; 1.99]$

$0.85[-0.12 ; 1.82]$

$2.20[-0.02 ; 4.42]$

$3.30[0.39 ; 6.21]$

$-0.10[-1.67 ; 1.47]$

$1.80[0.46 ; 3.14]$

$1.00[-2.37 ; 4.37]$

$0.80[-1.64 ; 3.24]$

$2.00[0.90 ; 3.10]$

$0.80[-0.75 ; 2.35]$

$-0.10[-1.60 ; 1.40]$

$-0.40[-1.90 ; 1.10]$

$3.40[1.90 ; 4.90]$

$0.80[-0.49 ; 2.09]$

Figure 4. Forest plot of the difference in means (MD) between multispecies and simple swards in daily milk yield (MY) and $95 \%$ CI for studies that investigated the effect of herb species inclusion in a grazed forage on MY of lactating dairy cows. Studies have been grouped according to swards containing chicory, plantain, or both. Studies are listed by first author's name and year, with multiple comparisons from the same study indicated by alphabetical notation. The MD of each comparison is represented by a square on each line. The line connected to each square indicates the $95 \%$ CI of the MD. Relative weighting of each comparison is represented by the gray box surrounding the MD, with larger squares representing greater weight. An MD to the left of the vertical line represents a reduction in the outcome, whereas an MD to the right of the line indicates an increase in the outcome of interest.

themselves. Furthermore, Bryant et al. (2017) concluded that the legume content of the sward influenced milk production more than did the number of species present in the sward mixture. Of the 25 comparisons in our analysis, all but 4 included WC in the simple sward. Subgroup analysis showed no difference in milk production between cows grazing simple swards containing grass only and those composed of a grass and 
Study

Stage of lactation = Early

Box et al, 2017b

Bryant et al, 2017a

Bryant et al, 2017d

Bryant et al, 2017g

Chapman et al, 2008

Stage of lactation $=$ Late

Box et al, 2017a

Bryant et al, 2017c

Bryant et al, 2017f

Bryant et al, 2017i

Bryant et al, 2018a

Bryant et al, 2018b

Dodd et al, 2018a

Dodd et al, 2018c

Minnee et al, 2017

Muir et al, 2015

Totty et al, 2013

Stage of lactation $=$ Mid

Bryant et al, 2017b

Bryant et al, 2017e

Bryant et al, 2017h

Dodd et al, 2018b

Dodd et al, 2018d

Jonker et al, 2018

Muir et al, 2014a

Muir et al, 2014b

Soder et al, 2006
MD $\quad 95 \% \mathrm{Cl}$

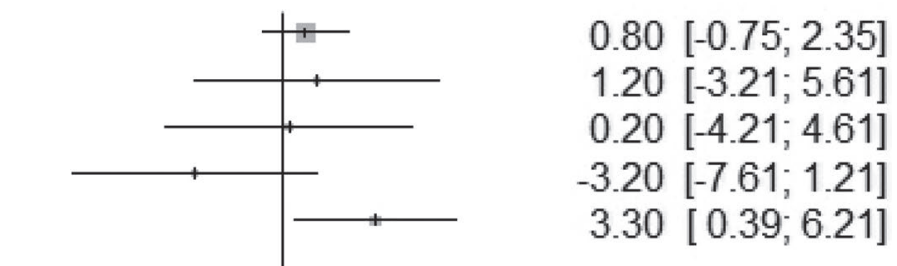

$2.00[0.90 ; 3.10]$

$0.10[-9.27 ; 9.47]$

$-0.60[-9.97 ; 8.77]$

$0.50[-8.87 ; 9.87]$

$2.60[-2.11 ; 7.31]$

$0.90[-3.81 ; 5.61]$

$-0.10[-1.60 ; 1.40]$

$3.40[1.90 ; 4.90]$

$0.85[-0.12 ; 1.82]$

$1.00[-2.37 ; 4.37]$

$2.20[-0.02 ; 4.42]$

$1.20[-4.37 ; 6.77]$

$-0.70[-6.27 ; 4.87]$

$-1.60[-7.17 ; 3.97]$

$-0.40[-1.90 ; 1.10]$

$0.80[-0.49 ; 2.09]$

$1.30[0.61 ; 1.99]$

$-0.10[-1.67 ; 1.47]$

$1.80[0.46 ; 3.14]$

$0.80[-1.64 ; 3.24]$

Figure 5. Forest plot of the difference in means (MD) between multispecies and simple swards in daily milk yield (MY) and 95\% CI for studies that investigated the effect of herb species inclusion in a grazed forage on MY of lactating dairy cows. Studies have been grouped according to stage of lactation: Early, Mid, or Late, equal to 67, 111, and 215 DIM on average, respectively. Studies are listed by first author's name and year, with multiple comparisons from the same study indicated by alphabetical notation. The MD of each comparison is represented by a square on each line. The line connected to each square indicates the $95 \%$ CI of the MD. Relative weighting of each comparison is represented by the gray box surrounding the MD, with larger squares representing greater weight. An MD to the left of the vertical line represents a reduction in the outcome, whereas an MD to the right of the line indicates an increase in the outcome of interest.

legume. However, our study did not extract data on the legume content of simple swards, and this may have a greater influence on the production response than does the simple presence of a legume species in the sward.

Through a meta-regression, we investigated whether there is an optimum inclusion percentage of herb species in a grazing sward to increase MY. In a previous meta- analysis assessing the optimum $\mathrm{WC}$ content in grazing swards to increase milk production, WC included at $31.6 \%$ increased daily MY and milk solids (Dineen et al., 2018). However, in our data, despite a positive relationship between herb percentage in the sward and MY, the association between herb percentage and MY was non-significant. Our analysis contained 25 comparisons, 
Table 4. Weighted mean difference (WMD), heterogeneity $\left(I^{2}\right), 95 \%$ CI, and number of studies and comparisons included in the analysis of sward nutritive characteristics extracted for random effect analysis comparing multispecies (herb-containing) and simple (non-herb-containing) swards; $P$-value indicates the level of significance between multispecies and simple sward groups for each outcome

\begin{tabular}{lcccrrr}
\hline $\begin{array}{l}\text { Item } \\
(\% \text { of DM) }\end{array}$ & WMD & $I^{2}(\%)$ & $95 \%$ CI & $\begin{array}{c}\text { No. of } \\
\text { studies }\end{array}$ & $\begin{array}{c}\text { No. of } \\
\text { comparisons }\end{array}$ & Coefficient SE \\
\hline DM & -2.93 & 17.5 & $-4.44,-1.43$ & 7 & 17 & 0.518 \\
CP & -0.07 & 72.6 & $-1.32,1.19$ & 11 & 24 & 0.545 \\
NDF & -6.76 & 66.0 & $-9.06,-4.47$ & 11 & 24 & 0.965 \\
ADF & -1.20 & 46.2 & $-2.53,0.14$ & 8 & 10 & 0.495 \\
WSC & 0.36 & 75.4 & $-2.78,3.49$ & 6 & 16 & 0.001 \\
OMD & -0.62 & 79.4 & $-5.17,3.93$ & 4 & 16 & 0.069 \\
\hline
\end{tabular}

${ }^{1} \mathrm{WSC}=$ water-soluble carbohydrates; OMD $=$ organic matter digestibility.

whereas the study by Dineen et al. (2018) consisted of 46 comparisons. More data may be required to allow estimation of an optimum inclusion rate for herb species in grazing swards.

\section{UN Excretion}

The effect of herb species on UN excretion is particularly interesting as attention is increasingly directed toward the environmental impacts of dairy production, particularly nitrogen losses, with a growing focus on developing more sustainable dairy systems. However, our analysis showed no effect of herb species inclusion in grazing swards on UN excretion in dairy cows.

Average UN excretion, in grams of nitrogen per day for cows in this analysis, was 332.8 and $289.6 \mathrm{~g}$ of $\mathrm{N} / \mathrm{d}$. Reducing the $\mathrm{CP}$ level of the dairy cow diet has been shown to reduce MUN, NPN, and UN excretion (Broderick, 2003), and a reduction in UN excretion was achieved when a low-CP concentrate was fed to cows grazing a PRG pasture (Mulligan et al., 2004). However, in pasture-based systems, the scope for dietary manipulation of nutrients is largely dependent on the nutrient profile within the pasture itself, as pasture is the main component of the diet. The use of high-sugar grasses, with increased water-soluble carbohydrate content, has previously been suggested as a means of increasing $\mathrm{N}$ utilization efficiency in the rumen and reducing UN excretion (Miller et al., 2001), although animal responses are variable (Edwards et al., 2007).

Secondary bioactive compounds in herb species, particularly in plantain, have been highlighted as possible explanatory factors in UN reduction among dairy cows. Plantain contains a dual defense system composed of glycosidic defense compounds, activated by enzymes, which exert biological effects (Pankoke et al., 2013). Glycosidic compounds such as aucubin are known to have diuretic effects (Tamura and Nishibe, 2002), with an increase in urination among dairy heifers grazing plantain previously noted (Cheng et al., 2017). The diuretic effect of aucubin may result in a reduced UN concentration in urine patches and lower $\mathrm{N}_{2} \mathrm{O}$ loss from pasture (Gardiner et al., 2016). Similarly, chicory is a low-DM herb with a high mineral content (Cheng et al., 2017), which can cause increased water intake and urination. In vitro fermentation of the secondary

Table 5. Average DM, CP, NDF, ADF, water-soluble carbohydrates (WSC), and organic matter digestibility (OMD) as a percentage of DM for multispecies and simple swards; average seasonal sward nutritive characteristics are presented according to stage of lactation: early, mid, and late

\begin{tabular}{|c|c|c|c|c|c|c|c|c|}
\hline \multirow{2}{*}{$\begin{array}{l}\text { Item } \\
\text { (\% of DM) }\end{array}$} & \multicolumn{8}{|c|}{ Treatment } \\
\hline & Average & Early & Mid & Late & Average & Early & Mid & Late \\
\hline $\mathrm{DM}$ & 16.0 & 15.4 & 15.4 & 16.6 & 19.5 & 18.6 & 20.4 & 19.4 \\
\hline SD & 3.96 & 2.25 & 3.89 & 4.87 & 4.02 & 2.30 & 4.11 & 4.82 \\
\hline $\mathrm{CP}$ & 17.6 & 14.6 & 16.5 & 19.7 & 18.2 & 15.2 & 16.8 & 20.6 \\
\hline $\mathrm{SD}$ & 7.76 & 13.12 & 7.77 & 5.29 & 8.97 & 13.66 & 7.28 & 5.87 \\
\hline $\mathrm{ADF}$ & 25.3 & 24.8 & 26.3 & 24.87 & 26.7 & 26.5 & 28.0 & 26.1 \\
\hline SD & 4.14 & 2.15 & 3.09 & 5.00 & 4.39 & 2.16 & 2.81 & 5.55 \\
\hline WSC & 18.2 & 18.0 & 19.4 & 17.7 & 19.7 & 21.0 & 20.1 & 18.1 \\
\hline $\mathrm{SD}$ & 5.56 & 4.03 & 6.63 & 5.27 & 5.52 & 4.60 & 6.14 & 5.12 \\
\hline OMD & 71.5 & 73.4 & 69.9 & 71.8 & 72.8 & 76.1 & 72.7 & 71.7 \\
\hline SD & 3.56 & 2.04 & 2.56 & 4.76 & 3.56 & 2.04 & 2.56 & 4.76 \\
\hline
\end{tabular}


compounds acteoside and aucubin has been shown to reduce $\mathrm{NH}_{3}$ production (Navarrete et al., 2016). Navarrete et al. (2016) suggested that aucubin reduced $\mathrm{NH}_{3}$ production via a bactericidal, and subsequently inhibitory, effect on rumen fermentation. In contrast, acteoside was proposed to have been used as an energy source by rumen microbes, improving $\mathrm{N}$ utilization.

\section{Applications and Limitations}

Perennial ryegrass is the most important pasture species in Ireland, accounting for $95 \%$ of all forage grass seed sold (DAFM, 2019). A key advantage of PRG swards is their suitability in rotational grazing systems. Perennial ryegrass is a high-quality feedstuff, capable of withstanding intensive grazing, and responds well to fertile conditions and nitrogen inputs (Shalloo et al., 2011). However, EU restrictions on fertilizer N inputs (DAFM, 2018) has resulted in renewed efforts to develop more sustainable production systems requiring less fertilizer $\mathrm{N}$ inputs. Although we did not see a reduction in UN excretion, previous research has demonstrated that the annual DM yield of multispecies swards is comparable to that of simple swards, with lower $\mathrm{N}$ fertilizer inputs (Nyfeler et al., 2009; Grace et al., 2018). Our analysis also highlights the potential production benefits of multispecies swards in pasture-based dairy systems, whereby an improvement in milk production was found. However, knowledge gaps still exist, relating to the management and suitability of these swards in rotational grazing systems. More information on animal performance, sward persistence, and changes in plant nutritive value over time, through long-term grazing studies, is required in order to further our knowledge of the applications and limitations of multispecies swards in grazing dairy production systems.

\section{CONCLUSIONS}

Despite the low number of studies available to evaluate our hypothesis, our analysis shows that multispecies swards improved the milk production of grazing dairy cows. Daily milk yield $(+1.20 \mathrm{~kg} / \mathrm{d}), \mathrm{ECM}(+1.30$ $\mathrm{kg} / \mathrm{d}$ ), and combined fat and protein in kilograms $(+0.06 \mathrm{~kg} / \mathrm{d})$ all increased significantly. However, we found no difference in DMI, which would preclude this as an explanation for the increased milk production observed. We also found no significant difference in UN excretion. Questions remain over the application of multispecies swards in grazing dairy systems. Continued research investigating management strategies for multispecies swards is needed to determine optimum grazing strategies for multispecies swards in modern pasture-based dairy systems.

\section{ACKNOWLEDGMENTS}

The experimental work reported herein was funded by the Department of Agriculture, Food and the Marine's Competitive Funding Programmes (17/S/267; Dublin, Ireland) in conjunction with commercial industry.

\section{REFERENCES}

Baker, W. L., C. M. White, J. C. Cappelleri, J. Kluger, and C. I. Coleman. 2009. Understanding heterogeneity in meta-analysis: The role of meta-regression. Int. J. Clin. Pract. 63:1426-1434. https:// doi.org/10.1111/j.1742-1241.2009.02168.x.

Bello, N. M., M. Kramer, R. J. Tempelman, W. W. Stroup, N. R. St-Pierre, B. A. Craig, L. J. Young, and E. E. Gbur. 2016. Short communication: On recognizing the proper experimental unit in animal studies in the dairy sciences. J. Dairy Sci. 99:8871-8879. https://doi.org/10.3168/jds.2016-11516.

Beukes, P. C., P. Gregorini, A. J. Romera, S. L. Woodward, E. N. Khaembah, D. F. Chapman, F. Nobilly, R. H. Bryant, G. R. Edwards, and D. A. Clark. 2014. The potential of diverse pastures to reduce nitrogen leaching on New Zealand dairy farms. Anim. Prod. Sci. 54:1971-1979. https://doi.org/10.1071/AN14563.

Box, L. A., G. R. Edwards, and R. H. Bryant. 2017. Milk production and urinary nitrogen excretion of dairy cows grazing plantain in early and late lactation. N. Z. J. Agric. Res. 60:470-482. https:// doi.org/10.1080/00288233.2017.1366924.

Broderick, G. A. 2003. Effects of varying dietary protein and energy levels on the production of lactating dairy cows. J. Dairy Sci. 86:1370-1381. https://doi.org/10.3168/jds.S0022-0302(03)73721 -7 .

Bryant, R. H., M. E. Miller, S. L. Greenwood, and G. R. Edwards. 2017. Milk yield and nitrogen excretion of dairy cows grazing binary and multispecies pastures. Grass Forage Sci. 72:806-817. https: //doi.org/10.1111/gfs.12274.

Bryant, R. H., B. G. Welten, D. Costall, P. R. Shorten, and G. R. Edwards. 2018. Milk yield and urinary-nitrogen excretion of dairy cows grazing forb pasture mixtures designed to reduce nitrogen leaching. Livest. Sci. 209:46-53. https://doi.org/10.1016/j.livsci .2018.01.009.

Cameron, K. C., H. J. Di, and J. L. Moir. 2013. Nitrogen losses from the soil/plant system: A review. Ann. Appl. Biol. 162:145-173. https://doi.org/10.1111/aab.12014.

Chapman, D. F., J. Tharmaraj, and Z. N. Nie. 2008. Milk-production potential of different sward types in a temperate southern Australian environment. Grass Forage Sci. 63:221-233. https://doi.org/ 10.1111/j.1365-2494.2008.00627.x.

Cheng, L., J. McCormick, A. N. Hussein, C. Logan, D. Pacheco, M. C. Hodge, and G. R. Edwards. 2017. Live weight gain, urinary nitrogen excretion and urination behaviour of dairy heifers grazing pasture, chicory and plantain. J. Agric. Sci. 155:669-678. https:// doi.org/10.1017/S0021859616001076.

Cranston, L. M., P. R. Kenyon, S. T. Morris, and P. D. Kemp. 2015. A review of the use of chicory, plantain, red clover and white clover in a sward mix for increased sheep and beef production. J. N. Z. Grassl. 77:89-94.

DAFM. 2018. Department of Agriculture, Food and the Marine. European Union (Good Agricultural Practice for Protection of Waters) Regulations 2018. Accessed Jul. 5, 2019. https://www.agriculture .gov.ie/ruralenvironmentsustainability/environmentalobligations/ nitrates/.

DAFM. 2019. Department of Agriculture, Food and the Marine. Grass and White Clover Varieties Irish Recommended List 2019. DAFM, Crop Policy, Evaluation and Certification Division, Backweston Farm, Leixlip, Kildare, Ireland.

de Vries, W., H. Kros, and O. Oenema. 2001. Modeled impacts of farming practices and structural agricultural changes on nitrogen fluxes in the Netherlands. ScientificWorldJournal 1:664-672. https: //doi.org/10.1100/tsw.2001.332. 
Dineen, M., L. Delaby, T. Gilliland, and B. McCarthy. 2018. Metaanalysis of the effect of white clover inclusion in perennial ryegrass swards on milk production. J. Dairy Sci. 101:1804-1816. https:// doi.org/10.3168/jds.2017-12586.

Dodd, M., D. Dalley, C. Wims, D. Elliott, and A. Griffin. 2018. A comparison of temperate pasture species mixtures selected to increase dairy cow production and reduce urinary nitrogen excretion. N. Z. J. Agric. Res. 62:1-24. https://doi.org/10.1080/00288233.2018 .1518246 .

Edwards, G., A. Parsons, S. Rasmussen, and R. H. Bryant. 2007. High sugar ryegrasses for livestock systems in New Zealand. Pages 161-171 in Proc. NZ Grassl. Assoc. 69, NZ Grassland Conference, Wairakei, NZ. NZ Grassland Assoc., Dunedin, New Zealand.

Egger, M., G. D. Smith, M. Schneider, and C. Minder. 1997. Bias in meta-analysis detected by a simple, graphical test. BMJ 315:629634. https://doi.org/10.1136/bmj.315.7109.629.

EUC (European Commission). 2017. Modernizing and simplifying the CAP. European Commission-Director General for Agriculture and Rural Development. Brussels, Belgium. Accessed Jul. 13, 2019. https://ec.europa.eu/agriculture/sites/agriculture/files/ consultations/cap-modernising/env_background_final_en.pdf.

Fadul-Pacheco, L., D. Pellerin, P. Y. Chouinard, M. A. Wattiaux, M. Duplessis, and É. Charbonneau. 2017. Nitrogen efficiency of eastern Canadian dairy herds: Effect on production performance and farm profitability. J. Dairy Sci. 100:6592-6601. https://doi.org/10 $.3168 /$ jds.2016-11788

Finn, J. A., L. Kirwan, J. Connolly, M. T. Sebastià, A. Helgadottir, O. H. Baadshaug, G. Bélanger, A. Black, C. Brophy, R. P. Collins, J. Čop, S. Dalmannsdóttir, I. Delgado, A. Elgersma, M. Fothergill, B. E. Frankow-Lindberg, A. Ghesquiere, B. Golinska, P. Golinski, P. Grieu, A. M. Gustavsson, M. Höglind, O. Huguenin-Elie, M. Jørgensen, Z. Kadziuliene, P. Kurki, R. Llurba, T. Lunnan, C. Porqueddu, M. Suter, U. Thumm, and A. Lüscher. 2013. Ecosystem function enhanced by combining four functional types of plant species in intensively managed grassland mixtures: A 3-year continental-scale field experiment. J. Appl. Ecol. 50:365-375. https:// doi.org/10.1111/1365-2664.12041.

Fisher, Z. and E. Tipton. 2015. robumeta: An R-package for robust variance estimation in meta-analysis. ArXiv150302220 Stat.

Gardiner, C. A., T. J. Clough, K. C. Cameron, H. J. Di, G. R. Edwards, and C. de Klein. 2016. Potential for forage diet manipulation in New Zealand pasture ecosystems to mitigate ruminant urine derived $\mathrm{N}_{2} \mathrm{O}$ emissions: A review. N. Z. J. Agric. Res. 59:301317. https://doi.org/10.1080/00288233.2016.1190386.

Grace, C., T. M. Boland, H. Sheridan, S. Lott, E. Brennan, R. Fritch, and M. B. Lynch. 2018. The effect of increasing pasture species on herbage production, chemical composition and utilization under intensive sheep grazing. Grass Forage Sci. 73:852-864. https://doi .org/10.1111/gfs.12379.

Hedges, L. V., E. Tipton, and M. C. Johnson. 2010. Robust variance estimation in meta-regression with dependent effect size estimates. Res. Synth. Methods 1:39-65. https://doi.org/10.1002/jrsm.5.

Higgins, J. P. T., and S. Green. 2011. Cochrane Handbook for Systematic Reviews of Interventions. 5.1.0. ed. The Cochrane Collaboration. John Wiley \& Sons Ltd., Hoboken, NJ.

Higgins, J. P. T., and S. G. Thompson. 2002. Quantifying heterogeneity in a meta-analysis. Stat. Med. 21:1539-1558. https://doi.org/ $10.1002 / \operatorname{sim} .1186$.

Jonker, A., L. Farrell, D. Scobie, R. Dynes, G. Edwards, H. Hague, R. McAuliffe, A. Taylor, T. Knight, and G. Waghorn. 2018. Methane and carbon dioxide emissions from lactating dairy cows grazing mature ryegrass/white clover or a diverse pasture comprising ryegrass, legumes and herbs. Anim. Prod. Sci. 59:1063-1069. https:// doi.org/10.1071/AN18019.

Lean, I. J., A. R. Rabiee, T. F. Duffield, and I. R. Dohoo. 2009. Invited review: Use of meta-analysis in animal health and reproduction: Methods and applications. J. Dairy Sci. 92:3545-3565. https://doi .org/10.3168/jds.2009-2140.

Lean, I. J., J. E. P. Santos, E. Block, and H. M. Golder. 2019. Effects of prepartum dietary cation-anion difference intake on production and health of dairy cows: A meta-analysis. J. Dairy Sci. 102:21032133. https://doi.org/10.3168/jds.2018-14769.

McAloon, C. G., P. Whyte, S. J. More, M. J. Green, L. O'Grady, A. Garcia, and M. L. Doherty. 2016. The effect of paratuberculosis on milk yield - A systematic review and meta-analysis. J. Dairy Sci. 99:1449-1460. https://doi.org/10.3168/jds.2015-10156.

Miller, L. A., J. M. Moorby, D. R. Davies, M. O. Humphreys, N. D. Scollan, J. C. MacRae, and M. K. Theodorou. 2001. Increased concentration of water-soluble carbohydrate in perennial ryegrass ( $\mathrm{Lo}$ lium perenne L.): Milk production from late-lactation dairy cows. Grass Forage Sci. 56:383-394. https://doi.org/10.1046/j.1365-2494 .2001.00288.x

Minneé, E. M. K., G. C. Waghorn, J. M. Lee, and C. E. F. Clark. 2017. Including chicory or plantain in a perennial ryegrass/white cloverbased diet of dairy cattle in late lactation: Feed intake, milk production and rumen digestion. Anim. Feed Sci. Technol. 227:52-61. https://doi.org/10.1016/j.anifeedsci.2017.03.008.

Moher, D., A. Liberati, J. Tetzlaff, D. G. Altman, and PRISMA Group. 2009. Preferred reporting items for systematic reviews and meta-analyses: The PRISMA statement. PLoS Med. 6:e1000097. https://doi.org/10.1371/journal.pmed.1000097.

Muir, S. K., G. N. Ward, and J. L. Jacobs. 2014. Milk production and composition of mid-lactation cows consuming perennial ryegrassand chicory-based diets. J. Dairy Sci. 97:1005-1015. https://doi .org/10.3168/jds.2013-7183.

Muir, S. K., G. N. Ward, and J. L. Jacobs. 2015. Herbage intake and milk production of late-lactation dairy cows offered a second-year chicory crop during summer. J. Dairy Sci. 98:8825-8835. https:// doi.org/10.3168/jds.2014-9147.

Mulligan, F. J., P. Dillon, J. J. Callan, M. Rath, and F. P. O'Mara. 2004. Supplementary concentrate type affects nitrogen excretion of grazing dairy cows. J. Dairy Sci. 87:3451-3460. https://doi.org/10 .3168/jds.S0022-0302(04)73480-3.

Navarrete, S., P. D. Kemp, S. J. Pain, and P. J. Back. 2016. Bioactive compounds, aucubin and acteoside, in plantain (Plantago lanceolata L.) and their effect on in vitro rumen fermentation. Anim. Feed Sci. Technol. 222:158-167. https://doi.org/10.1016/j .anifeedsci.2016.10.008.

Nyfeler, D., O. Huguenin-Elie, M. Suter, E. Frossard, J. Connolly, and A. Lüscher. 2009. Strong mixture effects among four species in fertilized agricultural grassland led to persistent and consistent transgressive overyielding. J. Appl. Ecol. 46:683-691. https://doi .org $/ 10.1111 / \mathrm{j} .1365-2664.2009 .01653 . x$.

Pankoke, H., T. Buschmann, and C. Müller. 2013. Role of plant $\beta$-glucosidases in the dual defense system of iridoid glycosides and their hydrolyzing enzymes in Plantago lanceolata and Plantago major. Phytochemistry 94:99-107. https://doi.org/10.1016/j .phytochem.2013.04.016

Pannell, D. J., G. R. Marshall, N. Barr, A. Curtis, F. Vanclay, and R. Wilkinson. 2006. Understanding and promoting adoption of conservation practices by rural landholders. Aust. J. Exp. Agric. 46:1407-1424. https://doi.org/10.1071/EA05037.

Pembleton, K. G., J. L. Hills, M. J. Freeman, D. K. McLaren, M. French, and R. P. Rawnsley. 2016. More milk from forage: Milk production, blood metabolites, and forage intake of dairy cows grazing pasture mixtures and spatially adjacent monocultures. J. Dairy Sci. 99:3512-3528. https://doi.org/10.3168/jds.2015-10542.

Pembleton, K. G., K. N. Tozer, G. R. Edwards, J. L. Jacobs, and L. R. Turner. 2015. Simple versus diverse pastures: Opportunities and challenges in dairy systems. Anim. Prod. Sci. 55:893-901. https:// doi.org/10.1071/AN14816.

Roca-Fernández, A. I., J. L. Peyraud, L. Delaby, and R. Delagarde. 2016. Pasture intake and milk production of dairy cows rotationally grazing on multi-species swards. Animal 10:1448-1456. https: //doi.org/10.1017/S1751731116000331.

Romera, A. J., G. J. Doole, P. C. Beukes, N. Mason, and P. L. Mudge. 2017. The role and value of diverse sward mixtures in dairy farm systems of New Zealand: An exploratory assessment. Agric. Syst. 152:18-26. https://doi.org/10.1016/j.agsy.2016.12.004. 
Rosenberg, M. S., K. A. Garrett, Z. Su, and R. L. Bowden. 2004. Meta-analysis in plant pathology: Synthesizing research results. Phytopathology 94:1013-1017. https://doi.org/10.1094/PHYTO 2004.94.9.1013.

Ryan, W., D. Hennessy, J. J. Murphy, T. M. Boland, and L. Shalloo. 2011. A model of nitrogen efficiency in contrasting grass-based dairy systems. J. Dairy Sci. 94:1032-1044. https://doi.org/10 $.3168 /$ jds.2010-3294.

Sanderson, M. A., K. J. Soder, L. D. Muller, K. D. Klement, R. H. Skinner, and S. C. Goslee. 2005. Forage mixture productivity and botanical composition in pastures grazed by dairy cattle. Agron. J. 97:1465-1471. https://doi.org/10.2134/agronj2005.0032.

Sauvant, D., P. Schmidely, J. J. Daudin, and N. R. St-Pierre. 2008. Meta-analyses of experimental data in animal nutrition. Animal 2:1203-1214. https://doi.org/10.1017/S1751731108002280.

Schwarzer, G. 2007. meta: An R package for meta-analysis. R News 7:40-45. https://cran.r-project.org/doc/Rnews/Rnews_2007-3 .pdf.

Shalloo, L., P. Creighton, and M. O'Donovan. 2011. The economics of reseeding on a dairy farm. Ir. J. Agric. Food Res. 50:113-122.

Soder, K. J., M. A. Sanderson, J. L. Stack, and L. D. Muller. 2006. Intake and performance of lactating cows grazing diverse forage mixtures. J. Dairy Sci. 89:2158-2167. https://doi.org/10.3168/jds .S0022-0302(06)72286-X.

Spek, J. W., J. Dijkstra, G. van Duinkerken, W. H. Hendriks, and A. Bannink. 2013. Prediction of urinary nitrogen and urinary urea nitrogen excretion by lactating dairy cattle in northwestern Europe and North America: A meta-analysis. J. Dairy Sci. 96:4310-4322. https://doi.org/10.3168/jds.2012-6265.

Tamura, Y., and S. Nishibe. 2002. Changes in the concentrations of bioactive compounds in plantain leaves. J. Agric. Food Chem. 50:2514-2518. https://doi.org/10.1021/jf011490x.
Tanner-Smith, E. E., and M. D. Risser. 2016. A meta-analysis of brief alcohol interventions for adolescents and young adults: Variability in effects across alcohol measures. Am. J. Drug Alcohol Abuse 42:140-151. https://doi.org/10.3109/00952990.2015.1136638.

Tanner-Smith, E. E., E. Tipton, and J. R. Polanin. 2016. Handling complex meta-analytic data structures using robust variance estimates: A tutorial in R. J. Dev. Life Course Criminol. 2:85-112. https://doi.org/10.1007/s40865-016-0026-5.

Tipton, E. 2015. Small sample adjustments for robust variance estimation with meta-regression. Psychol. Methods 20:375-393. https:// doi.org/10.1037/met0000011.

Totty, V. K., S. L. Greenwood, R. H. Bryant, and G. R. Edwards. 2013. Nitrogen partitioning and milk production of dairy cows grazing simple and diverse pastures. J. Dairy Sci. 96:141-149. https://doi.org/10.3168/jds.2012-5504.

Tyrrell, H. F., and J. T. Reid. 1965. Prediction of the energy value of cow's milk. J. Dairy Sci. 48:1215-1223. https://doi.org/10.3168/ jds.S0022-0302(65)88430-2.

Vibart, R. E., I. Vogeler, M. Dodd, and J. Koolaard. 2016. Simple versus diverse temperate pastures: Aspects of soil-plant-animal interrelationships central to nitrogen leaching losses. Agron. J. 108:2174-2188. https://doi.org/10.2134/agronj2016.04.0193.

Whelan, S. J., F. J. Mulligan, and K. M. Pierce. 2013. Nitrogen efficiency in contrasting dairy production systems. Adv. Anim. Biosci Camb. 4: 9-14. https://doi.org/10.1017/S2040470013000253.

\section{ORCIDS}

K. M. McCarthy (® https://orcid.org/0000-0002-8362-5553

K. M. Pierce @ https://orcid.org/0000-0002-2056-6189

F. J. Mulligan ๑ https://orcid.org/0000-0002-1787-0788 